GRASAS Y ACEITES 67 (1)

January-March 2016, e112

ISSN-L: 0017-3495

doi: http://dx.doi.org/10.3989/gya.0250151

\title{
The role of the canonical biplot method in the study of volatile compounds in cheeses of variable composition
}

\author{
M.I. González-Martín ${ }^{\mathrm{a}, \bowtie}$, S. Vicente-Tavera ${ }^{\mathrm{b}}$, I. Revillac ${ }^{\mathrm{c}}$, A.M. Vivar-Quintana ${ }^{\mathrm{c}}$, \\ C. González-Pérez ${ }^{\mathrm{a}}$, J.M. Hernández Hierro ${ }^{\mathrm{d}}$ and I. Lobos-Ortega ${ }^{\mathrm{a}}$ \\ ${ }^{a}$ Departamento de Química Analítica, Nutrición y Bromatología, Facultad de \\ Ciencias Químicas, C/Plaza de la Merced s/n. 37008 Salamanca, España \\ ${ }^{\mathrm{b}}$ Departamento de Estadística, Facultad de Economía y Empresa, Universidad \\ de Salamanca C/Alfonso X El Sabio s/n, 37002 Salamanca, Spain \\ 'Área de Tecnología de los Alimentos, Escuela Politécnica Superior de Zamora Avda. Requejo 33, 49022 Zamora, España \\ ${ }^{\mathrm{d}}$ Food Colour \& Quality Lab., Dept. of Nutrition \& Food Science, Universidad de Sevilla, Facultad de Farmacia, 41012 Sevilla, Spain \\ ${ }^{\bowtie}$ Corresponding author: inmaglez@usal.es
}

Submitted: 18 February 2015; Accepted: 06 July 2015

SUMMARY: The canonical biplot method (CB) is used to determine the discriminatory power of volatile chemical compounds in cheese. These volatile compounds were used as variables in order to differentiate among 6 groups or populations of cheeses (combinations of two seasons (winter and summer) with 3 types of cheese (cow, sheep and goat's milk). We analyzed a total of 17 volatile compounds by means of gas chromatography coupled with mass detection. The compounds included aldehydes and methyl-aldehydes, alcohols (primary, secondary and branched chain), ketones, methyl-ketones and esters in winter (WC) and summer (SC) cow's cheeses, winter (WSh) and summer (SSh) sheep's cheeses and in winter (WG) and summer (SG) goat's cheeses. The CB method allows differences to be found as a function of the elaboration of the cheeses, the seasonality of the milk, and the separation of the six groups of cheeses, characterizing the specific volatile chemical compounds responsible for such differences.

KEYWORDS: Canonical biplot; Cheeses; Seasonality; Type of milk (cow, sheep, goat); Volatiles

RESUMEN: Papel del método biplot canónico en el estudio de compuestos volátiles en quesos de composición variable. El método biplot canónico $(\mathrm{CB})$ se utiliza para determinar el poder discriminatorio de compuestos químicos volátiles en queso. Los compuestos volátiles se utilizan como variables con el fin de diferenciar entre los 6 grupos o poblaciones de quesos (combinaciones de dos temporadas (invierno y verano) con 3 tipos de queso (vaca, oveja y cabra). Se analizan un total de 17 compuestos volátiles por medio de cromatografía de gases acoplada con detección de masas. Los compuestos incluyen aldehídos y metil-aldehídos, alcoholes (primarios de cadena, secundaria y ramificada), cetonas, metil-cetonas y ésteres. Los seis grupos de quesos son, quesos de vaca de invierno (WC) y verano (SC); quesos de oveja de invierno (WSh) y verano (SSh) y quesos de cabra de invierno (WG) y verano (SG). El método CB permite la separación de los seis grupos de quesos y encontrar las diferencias en función del tipo y estacionalidad de la leche, caracterizando los compuestos químicos volátiles específicos responsables de tales diferencias.

PALABRAS CLAVE: Compuestos volátiles; Estacionalidad; Quesos; Tipo de leche (vaca, oveja, cabra)

Citation/Cómo citar este artículo: González-Martín MI, Vicente-Tavera S, Revilla I, Vivar-Quintana AM, GonzálezPérez C, Hernández Hierro JM, Lobos-Ortega I. 2016. The role of the canonical biplot method in the study of volatile compounds in cheeses of variable composition. Grasas Aceites 67 (1): e112. doi: http://dx.doi.org/10.3989/gya.0250151.

Copyright: (C) 2016 CSIC. This is an open-access article distributed under the terms of the Creative Commons Attribution-Non Commercial (by-nc) Spain 3.0 Licence. 


\section{INTRODUCTION}

The aroma of a cheese is an important factor when it is acquired. The typical flavor of each variety of cheese is the result of a complex balance between volatile and non-volatile compounds originated during the ripening process from milk fats, proteins and carbohydrates. (Pillonel et al., 2003; Fox and Wallace, 1997).

The importance of volatile compounds is due to their correlation with the flavor, which depends on the ripening, time, cheese technology, seasonality, etc. The volatile fractions of some Iberian Peninsula cheeses such as Manchego (Gómez-Ruiz et al., 2002), Roncal (Izco and Torre, 2000), Zamorano (Barron et al., 2005a, Fernández-García et al., 2004a), Serra da Estrela (Dahl et al., 2000; Tavaria et al., 2004; Tavaria et al. 2006) have been studied as a response to the growing interest in the characterization of traditional products protected by a Denomination of Origin.

Canonical biplot (Vicente-Villardón, 1992), when it is oriented to the discrimination between groups or MANOVA-biplot (Gabriel, 1971; Galindo, 1986), when the aim is to study the variables responsible for the discrimination, are two effective methods. The main advantage to the biplot version of the technique is that it is possible not only for establishing the differences between groups but also to characterize the variables responsible for them.

Classic multivariate techniques, such as Principal Component Analysis and Canonical Correlation have been applied, among other areas, in fresh fruit (King et al., 2012), in the characterization of the sensory properties and texture of French cheeses (Antoniou et al., 2000), and to study the effects of mixtures of fats in the texture and sensory properties of cheeses (Lobato-Calleros et al., 1997). The Canonical biplot method has been used in the conservation of historical buildings and monuments (Varas et al., 2005), in civil engineering (Iñigo et al., 2005; Iñigo et al., 2013) and, in the case of foods, in the study of margarines (Rui Alves and Beatriz Oliveira, 2003), but no reference has been found regarding its application to the characterization of cheeses using volatile compounds as variables.

Taking into account that the volatile composition of cheese shows significant changes during the ripening period (Fernández-García et al., 2004a; Fernández-García et al., 2004b; Innocente et al., 2013), cheeses ripened from 0 to 6 months have been analyzed to obtain the characteristic profile of the samples throughout the ripening stage.

Here we used the Canonical biplot method to study which volatiles from the cheeses studied were most affected by each of the factors explored: the type of milk used to elaborate the cheeses (cow, sheep, goat) and the seasonality of the milk (winter, summer).

\section{MATERIAL AND METHODS}

\subsection{Samples and cheese-making procedure}

To perform the present study a total of 48 cheeses of known composition were elaborated and controlled. Cheeses were prepared in the laboratory, according to the following procedure: raw milk $(40 \mathrm{~L})$, not standardized, was incubated with $15 \mathrm{mg} \cdot \mathrm{L}^{-1}$ directvat-set starter made of Strepetococcuslactis, cremoris and diacetilactis (MA400, Arroyo Laboratories, Santander, Spain) at $30^{\circ} \mathrm{C}$. After $10 \mathrm{~min}$ at $32^{\circ} \mathrm{C}$, $12.5 \mathrm{mg} \cdot \mathrm{L}^{-1}$ of calf rennet $(90 \%$ chymosin, $10 \%$ trypsin and 1:150,000 strength) were added to each vat. Coagulation was allowed to take place over 20-70 min. When the curds had developed the desired firmness, evaluated subjectively, they were cut with a cheese harp until pieces similar in size to a grain of rice were obtained. Then, the curd was stirred for $30 \mathrm{~min}$, and heated for $10-20 \mathrm{~min}$ at $37^{\circ} \mathrm{C}$ until it had reached the desired consistency to improve its drainage with sieves. The curd was packed in round hoops $(1 \mathrm{~kg})$ and pressed for $6 \mathrm{~h}$ at $1.5 \mathrm{~kg} \mathrm{~cm}^{-2}$ at $20^{\circ} \mathrm{C}$. After pressing, the cheeses were salted by soaking them in a sodium chloride brine $(18 \%)$ at $18^{\circ} \mathrm{C}$ for $6 \mathrm{~h}$. The cheeses were then moved to a drying chamber, where temperature $\left(15^{\circ} \mathrm{C}\right)$ and relative humidity $(70 \%)$ were controlled. They were made of milk collected directly from farms in winter and summer; bovine, ovine and caprine raw milks were obtained directly from the producers in Zamora (Spain). Cheeses with 16 different compositions were elaborated, prepared with known, varying amounts of milk from cows, sheep and goats, with percentages ranging between 0,25 , 75 and $100 \%$. These cheeses were cylindrical, with an initial diameter of $10 \mathrm{~cm}$ and a thickness of $5 \mathrm{~cm}$ and they were monitored over 6 months (at $0.2,1,2,3,4$, 5 and 6 months) using one of the pieces each time. With respect to all the cheeses elaborated, Table 1 shows the number of samples of the 48 cheeses analyzed, their composition, the ripening time and the season (summer or winter) when the milk was collected (González-Martín et al., 2007).

\subsection{Analysis of volatile compounds}

Sample preparation, concentration of volatile compounds and gas chromatography coupled with mass detection were carried out at the Estación Tecnológica de la Leche (Instituto Tecnológico Agrario, Junta de Castilla y León, Palencia, Spain) in accordance with the following procedure: a $25-\mathrm{g}$ piece of cheese without rind was homogenized in an analytical grinder. $1 \mathrm{~g}$ of the ground sample was weighed in an assay tube with $2 \mathrm{~g}$ of $\mathrm{Na}_{2} \mathrm{SO}_{4}$ and $0.2 \mathrm{~mL}$ of cyclohexanone $50 \mathrm{mg} \cdot \mathrm{mL}^{-1}$ as internal standard and the mixture was homogenized. The sample was heated at $40^{\circ} \mathrm{C}$ and afterwards purged with helium $\left(40 \mathrm{~mL} \cdot \mathrm{min}^{-1}\right.$ for $\left.20 \mathrm{~min}\right)$. 
The role of the canonical biplot method in the study of volatile compounds in cheeses of variable composition $\bullet 3$

TABLE 1. Composition and number of samples of cheeses analyzed

\begin{tabular}{|c|c|c|c|c|c|}
\hline \multirow[b]{2}{*}{ Composition } & \multirow{2}{*}{$\begin{array}{c}N^{\circ} \text { of } \\
\text { samples }\end{array}$} & \multirow[b]{2}{*}{ Month of ripening } & \multirow[b]{2}{*}{ Seasonality } & \multicolumn{2}{|c|}{$\%$ Fat } \\
\hline & & & & $\mathbf{S}$ & $\mathbf{W}$ \\
\hline $100 \%$ Cow & 6 & $1,2,3,4,5,6$ (1 sample) & $3(\mathrm{~W}), 3(\mathrm{~S})$ & 30.33 & 32.6 \\
\hline $100 \%$ Sheep & 6 & $1,2,3,4,5,6$ (1 sample) & $3(\mathrm{~W}), 3(\mathrm{~S})$ & 44.6 & 50.0 \\
\hline $100 \%$ Goat & 6 & $1,2,3,4,5,6$ (1 sample) & $3(\mathrm{~W}), 3(\mathrm{~S})$ & 38.6 & 51.3 \\
\hline $25 \%$ Cow $75 \%$ Sheep & 6 & $1,2,3,4,5,6$ (1 sample) & $3(\mathrm{~W}), 3(\mathrm{~S})$ & 34.6 & 47.0 \\
\hline $25 \%$ Cow $75 \%$ Goat & 6 & $1,2,3,4,5,6$ (1 sample) & $3(\mathrm{~W}), 3(\mathrm{~S})$ & 34.0 & 46.0 \\
\hline $25 \%$ Sheep $75 \%$ Goat & 6 & $1,2,3,4,5,6$ (1 sample) & $3(\mathrm{~W}), 3(\mathrm{~S})$ & 36.3 & 45.6 \\
\hline $75 \%$ Cow $25 \%$ Goat & 6 & $1,2,3,4,5,6$ (1 sample) & $3(\mathrm{~W}), 3(\mathrm{~S})$ & 31.3 & 38.0 \\
\hline $75 \%$ Ewe $25 \%$ Goat & 3 & 4,5,6 (1sample) & $2(\mathrm{~W}), 1(\mathrm{~S})$ & 41.0 & 49.0 \\
\hline $75 \%$ Cow $25 \%$ Sheep & 3 & 4,5,6 (1 sample) & $2(\mathrm{~W}), 1(\mathrm{~S})$ & 36.0 & 38.0 \\
\hline
\end{tabular}

Winter: W, Summer: S.

Volatile compounds were concentrated in a Tenax/ Charcoal trap (Tekmar, Cincinnati, USA) and then desorbed using a helium flux $\left(40 \mathrm{~mL} \cdot \mathrm{min}^{-1}\right)$ for $20 \mathrm{~min}$ at $40^{\circ} \mathrm{C}$. The volatile compounds were separated and detected in a gas chromatograph (HP 7695, Hewlett-Packard, Palo Alto, USA) coupled with a mass detector (G1800A, Hewlett-Packard) fitted with a 19091N-136, HP INNOWAX column $(60 \mathrm{~m} \times 0.25 \mathrm{~mm}$ o.d., film thickness $0.5 \mu \mathrm{m}$, Agilent Technologies, Las Rozas, Spain). The helium flux was $1.0 \mathrm{~mL} \cdot \mathrm{min}^{-1}$ and the temperature gradient started at $45^{\circ} \mathrm{C}$, increasing by $4.0^{\circ} \mathrm{C} \cdot \mathrm{min}^{-1}$ up to $110^{\circ} \mathrm{C}$, then remaining at this temperature for $10 \mathrm{~min}$, after which the temperature was raised to $240^{\circ} \mathrm{C}$ at $18.0^{\circ} \mathrm{C} \cdot \mathrm{min}^{-1}$.

Detection was performed with the mass selective detector (HP5973) operating in the scan mode, 2.6 scan s$^{-1}, \mathrm{~m} / \mathrm{z}$ range $33-250$, with $70 \mathrm{eV} \mathrm{IE}$, and a detector temperature of $250{ }^{\circ} \mathrm{C}$. Analyses were carried out in duplicate. Peak identification was accomplished by comparison of retention times with authentic standards (Sigma Aldrich Química) and comparison of spectra with bibliographical data from the Wiley 275 library (Wiley and Sons, Inc., Germany). Quantification was measured as the sum of the abundance of all the ions (TIC), with reference to the cyclohexanone, which was added as the internal standard. Data are presented as relative abundances, the compounds' quantified compiling functional groups were aldehydes (acetaldehyde, propanal), methyl aldehydes (3methyl-butanal), primary alcohols (ethanol, propanol, butanol), secondary alcohols (2-butanol, 2-pentanol, isopropanol, 2-heptanol), branched-chain alcohols (3-methyl- 1-butanol), ketones (acetone), methyl ketones ( 2 butanone, 2 heptanone, 2-nonanone, 2-pentanone), and ester (ethyl acetate). Although the number of volatiles detected was higher, we only considered those that appeared in all the samples (The results of the composition of volatile are shown in the work of Gonzalez-Martín et al., 2014).

\subsection{Statistical analyses (Canonical biplot)}

Canonical biplot is a method of multivariate analysis which permits simultaneous plots of the different groups to be compared and the different variables under analysis to be obtained, but with the intrinsic characteristics of biplot methods (Gabriel 1971; Galindo 1986; Amaro et al., 2004).

To implement the technique, we started from a matrix of dimension (nxp), where the $\mathrm{n}$ rows were divided into k groups. After the corresponding decomposition into single values (SVD) of the matrix of the means of the groups, we built a biplot representation (in dimension r) (Vicente-Villardón 1992, 2013). We represented the row markers as points (stars for the average values of the different groups; +for the different elements of the groups) and the column markers as vectors in a scatter diagram. The Euclidean distance between two row markers approximates the Mahalanobis distance between groups and elements, i. e. the row markers are the coordinates of the group means on the canonical subspace with maximum discriminatory power.

Canonical biplot is oriented towards the discrimination between groups obtained with the MANOVA-biplot in order to study the variables responsible for the discrimination. The main advantage of the Canonical biplot version that uses this technique is that it offers the possibility not only of establishing the differences between groups but also of characterizing the specific variables that cause those differences. The results are usually summarized on different factorial planes that depend on the absorption of variance or dimensions that we retain $(\mathrm{r})$. The description of Canonical biplot method is described in the literature (Varas et al., 2005).

The Canonical biplot Analysis offers different analyses in a single plane and the interpretations can be directed to answer the issues of the study by 
comparing and contrasting groups and variables and focusing on their outstanding differences and similarities. This statistical method is not yet widely used, mainly because it is still not available in the major statistical packages. Generally, the biplot method includes t-tests based on Wilk's Lambda distribution, a probability distribution used in multivariate hypothesis testing. It is a multivariate generalization of the univariate F-distribution similar to Student's t-distribution. ANOVA and MANOVA tests in a single numerical table can be analyzed easily by following the graphic representation of the results. For statistical analysis we used a free application specifically constructed for biplot (VicenteVillardón, 2013).The Canonical biplot analysis was applied to a matrix formed of 17 variables and 48 rows in 6 groups accounting for combinations of two seasons (winter and summer) with three types of cheese (goat, cow and sheep's milk); that is, Winter Cow (WC), Summer Cow (SC); Winter Sheep (WSh), Summer Sheep (SSh), and Winter Goat (WG), Summer Goat (SG).

\section{RESULTS AND DISCUSSION}

The application of individual ANOVAs to the variables analyzed, (Table 2), shows that the variables isopropanol, 2-butanone, 2-butanol, propanol, 3-methyl-1-butanol, propanal, 3-methylbutanal and butanol did not have discriminatory power since they gave a result of $\mathrm{p}>0.05$.

The results of the Canonical biplot are shown in Table 3, where it may be seen that the variance of the three main axes accounts for $89.175 \%$ of the variance explained. The global contrast based on Wilk's Lambda test has a value of 2.5647 , with $\mathrm{p}<0.01$, indicating that, globally, differences are present between the 6 groups of populations of cheeses to be compared (WC), (SC), (WSh), (SSh), (WG), (SG).

On the factorial planes (Figure 1a) Axis 1 vs. Axis 2; b) (Figure 1b), Axis 1 vs. Axis 3; c) (Figure 1c), Axis 2 vs. Axis 3), the labels with poor, acceptable and good quality of representation appear respectively in grey, normal font and in bold. The interpretation of the labels depends on a series of measurements such as the quality of representation for the different planes (variance absorption of the planes, the goodness of the projections of the measurements on the variables for the dimensions selected, etc.) (Gabriel, 1971; Gabriel and Odoroff, 1990; Galindo, 1986).

In general, the quality of representation of the projected groups and variables on the first three planes is good, with the exception of that of SC, which is acceptable, and butane, which is poor. Upon analyzing the first two factorial planes (Figure 1a, b) it may be seen that the group of cheeses from winter cow's milk (WC) is clearly separated from the rest of the groups. Analyzing the variables responsible for this separation, it may be seen that this difference is due to the fact that the samples take higher values in ethanol, ethyl acetate, acetaldehyde and 2-butanol, together with lower values in 2-heptanone, 2-pentanone, isopropanol, 2-pentanol, acetone and 2-heptanol. This result is in agreement with previous works indicating that ethanol is present at higher concentrations in cow's cheese than in

TABLE 2. Individual ANOVAs

\begin{tabular}{lccccc}
\hline Variable & Total & Explained & Residual & F & Sign. \\
\hline Acetaldehyde & 48 & 14.781 & 33.219 & 3.738 & 0.00688 \\
Acetona & 48 & 18.706 & 29.294 & 5.364 & 0.00067 \\
isopropanol & 48 & 5.321 & 42.679 & 1.047 & 0.40298 \\
acetatodeetilo & 48 & 21.577 & 26.423 & 6.859 & $9 \mathrm{e}-005$ \\
2-butanone & 48 & 5.711 & 42.289 & 1.134 & 0.35735 \\
Ethanol & 48 & 21.125 & 26.875 & 6.603 & 0.00013 \\
2-pentanone & 48 & 13.704 & 34.296 & 3.356 & 0.0122 \\
2-butanol & 48 & 10.731 & 37.269 & 2.419 & 0.05149 \\
Propanol & 48 & 8.853 & 39.147 & 1.9 & 0.11478 \\
2-pentanol & 48 & 16.245 & 31.755 & 4.297 & 0.00302 \\
2-heptanone & 48 & 18.137 & 29.863 & 5.102 & 0.00096 \\
3-methyl-1-butanol & 48 & 6.215 & 41.785 & 1.249 & 0.3036 \\
2-nonanone & 48 & 14.512 & 33.488 & 3.64 & 0.00796 \\
Propanal & 48 & 8.673 & 39.327 & 1.853 & 0.1234 \\
3-methylbutanal & 48 & 4.208 & 43.792 & 0.807 & 0.55111 \\
Butanol & 48 & 4.859 & 43.141 & 0.946 & 0.46146 \\
2-heptanol & 48 & 19.055 & 28.945 & 5.53 & 0.00053 \\
\hline
\end{tabular}

The individual $F$ statistics follow a Snedecor's F with 5 and 42 d.f. 
The role of the canonical biplot method in the study of volatile compounds in cheeses of variable composition $\bullet 5$

TABLE 3. Eigenvalues and explained variance

\begin{tabular}{lccccccl}
\hline Dimension & Eigenv. & \% Expl. & Cumm. & TSS & ESS & F & p-val \\
\hline 1 & 2.039 & 43.572 & 43.572 & 5.156 & 4.156 & 34.911 & 0 \\
2 & 1.637 & 28.09 & 71.662 & 3.679 & 2.679 & 22.506 & 0 \\
3 & 1.292 & 17.513 & 89.175 & 2.67 & 1.67 & 14.032 & 0 \\
4 & 0.737 & 5.7 & 94.875 & 1.544 & 0.544 & 4.567 & 0.002 \\
5 & 0.699 & 5.125 & 100 & 1.489 & 0.489 & 4.106 & 0.004 \\
\hline
\end{tabular}

Global contrast based on Wilk's Lambda: 2.5647.

The F statistics follows a Snedecor's F with 85 and130 d.f. p-value: 6.241e-007.

sheep's cheese (Molina et al., 1999), while acetaldehyde is not one of the more important aldehydes in sheep's cheese (Barron, et al., 2005b; FernándezGarcía et al., 2004a, b) and it could not be found in goat's cheese (Castillo et al., 2007).

There is a clear difference between the WC and WG winter cheeses and the rest of the cheeses made in summer. This difference is hardly noticeable in the sheep cheeses (WS and SSh). The sheep cheeses (Figure 1a) were characterized by higher contents of methyl-ketones (2-pentanone, 2-heptanone and 2-nonanone), confirming earlier results indicating that methyl-ketones are compounds that appear in greater amounts and proportion in sheep cheeses (Barron et al., 2005a).
Regarding goat cheeses, these were characterized (Figure 1b) by 3-methyl-1- butanal and 3-methyl-1butanol. The presence of this alcohol is a consequence of the reduction in the aldehyde and it has previously been reported that it is present at a higher level in goat's milk cheese than in cow and sheep's milk cheeses (Molina et al., 1999).

Regarding the variables, propanal clearly separates the winter from the summer cheeses $(\mathrm{p}<0.05)$ since it takes the lowest values in winter in comparison with the higher values found for summer. When the mean values of the six groups of cheeses are projected onto the propanal variable, it can be observed that winter milk cheeses WC, WG, WSh show lower values than their summer equivalents
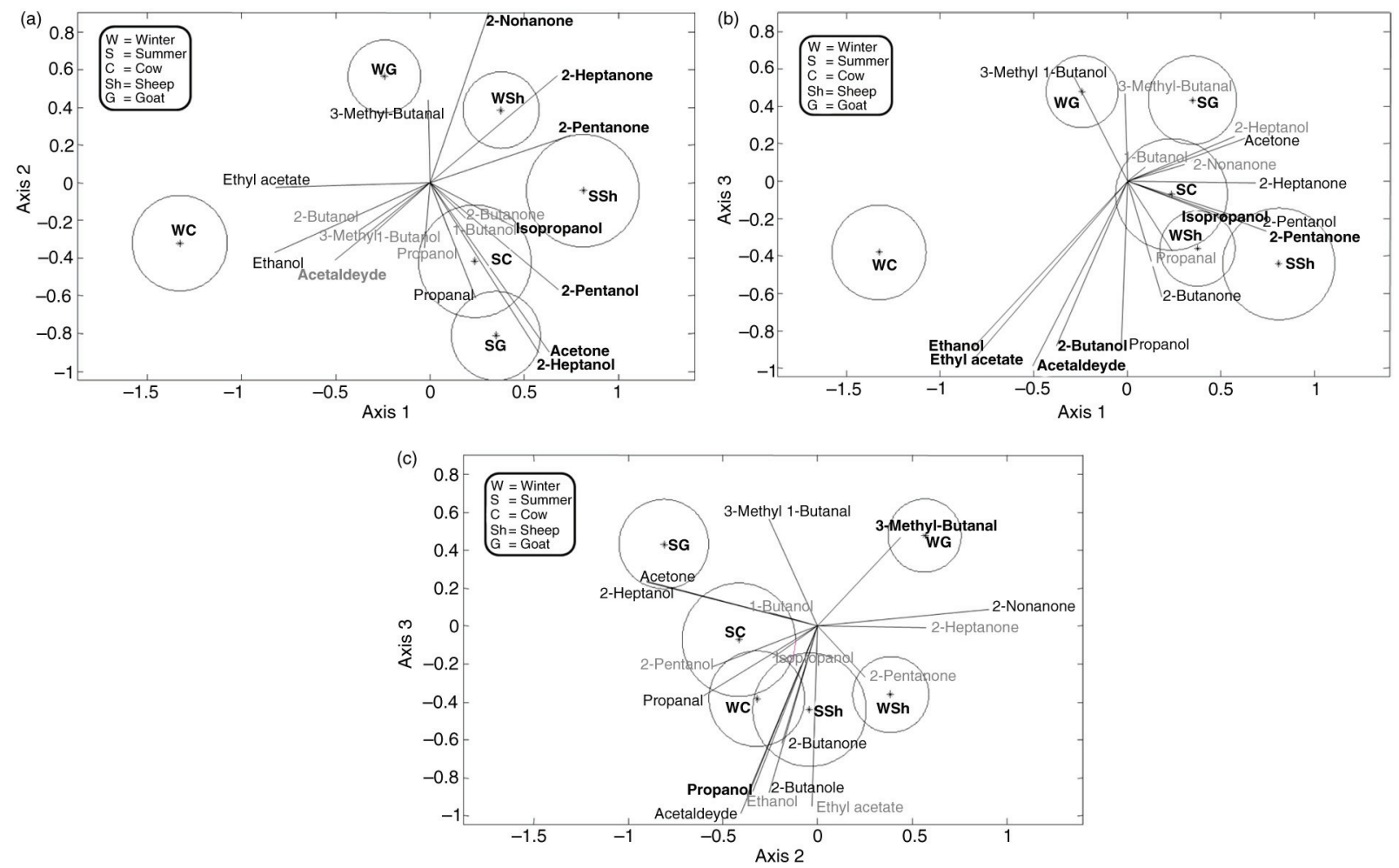

Figure 1. (a) Canonical biplot representation: axes 1 and 2. (b) Canonical biplot representation: axes 1 and 3. (c) Canonical biplot representation: axes 2 and 3 . 
(SC, SG, SSh). The same results have been obtained in Zamorano cheeses by Fernández-García et al., (2004a), who found the highest values of propanal in summer cheeses, with lower values in autumn and winter. This compound, as all the aldehydes, appears in very low concentration since it is an intermediate and unstable compound which is usually reduced to alcohols.

The same difference, although less pronounced, can be seen in the variables 2-pentanol, acetone, 2-heptanol and isopropanol (Figure 1a). These results are in agreement with those reported previously. Thus, Fernández-García et al. (2004a, b), found lower values of propanal in winter cheeses while 2-pentanol and 2-heptanol were significantly lower in autumn cheeses and no significant differences were observed for 2-propanol. In Figure 1b it may be seen that the parameters ethanol, ethyl acetate 2-butanol, acetaldehyde and propanol are detectors of winter cow's cheese samples owing to their higher mean values than the rest. The parameters 3 methyl 1butanol, 3 methyl butanal separate the goat (WG, SG) and sheep samples (WSh, SSh), (Figure 1b, Axis 1-Axis 3). The parameter 2-butanone separates goat's cheese since it was not possible to detect it in a large number of the samples of this cheese. In Figure 1c, Axis 1 vs. Axis 3, the parameter 3 methyl butanal is responsible for the statistically significant differences between the winter and summer goat's cheeses, together with acetone and 2-heptanol, which also show differences between winter and summer with the rest of the samples.

With respect to the seasonality of the cheeses, a comparative analysis between the same cheese made at different times of the year ( $\mathrm{W}$ and $\mathrm{S}$ ) afforded the following results: the WC group vs. SC differs $(p<0.05)$ in all the variables, but mainly in ethanol, acetaldehyde, 2-pentanone, 2-heptanone and 2-butanol. On comparing WG and SG, these differ $(p<0.05)$ in most of the variables, but mainly in the variables 3-methyl butanal (Figure 1c) and acetone, 2-heptanol and 2-pentanol. (Figure 1a, b). Fedele et al., 2005, found that goat winter milk had smaller amounts of ketones and more alcohols than summer milk. However, they did not find significant variations in the volatile compounds of goat cheeses from one season to another. The WSh group vs. SSh only differed $(p<0.05)$ in the variables isopropanol, 2-pentanol, acetone, 2-heptanol and propanal. 2-propanone has been found to be higher in winterautumn sheep cheeses, while heptanol, isopropanol and 2-pentanol are less abundant in these cheeses (Fernández-García et al., 2004a, b).

These results are due to the fact that the concentration and composition of various milk components differ according to season. Differences in the amount and composition of milk fat have been reported (Johansen et al., 2002, Nudda et al., 2005) owing to variations in feed factors. During the first months of the year the forage consumed tended to be mainly hay ( $98 \%$ of dry matter) with a small contribution from silages, less than $30 \%$ of the ration. From spring to summer the contribution of silage, first cuts, green forages etc., increased even if the animals remained in the pens. This type of diet reduces the dry matter intake. Afterwards, from summer to winter the diets were standardized and were composed of $40 \%$ hay and a $30 \%$ silages. When summer and winter diets are compared, although the composition was similar, the ration changes, in fact, because the animals tend to eat more in winter than in summer due to the number of daylight hours and temperatures. Indeed, the rumen metabolism is also affected because of the contributions of melatonin in the blood that affect both the ruminal bacteria populations and rumen parasympathetic regulation. Therefore, there are modifications in food intake, food composition, rumen activity, ruminal flora and circadian rhythms that affect cheese composition.

Thus, the fat contents ( $\%$ by weight) of the winter cheeses analyzed in this work had higher values than those of the summer cheeses (González-Martín et al., 2011). Moreover, important properties such as the protein:fat ratio and the casein:whey protein ratio are seen to be affected by time of year (Barron et al., 2001; Sitzia et al., 2015; Addis et al., 2015). Since volatile compounds are formed through the degradation of amino acids, leading to amines, aldehydes, alcohols, acids and sulfur compounds, and the breakdown of fatty acids, which produces esters, methyl ketones and secondary alcohols, the above changes in milk composition will affect the volatility profile.

\section{CONCLUSIONS}

The present results show that the volatile chemical compounds used as variables in the Canonical biplot method are suitable for establishing relationships between the significant variables (graphically and quantitatively) and the six groups of cheese: Winter Cow, Summer Cow, Winter Sheep, Summer Sheep, Winter Goat, Summer Goat. Winter cow's milk cheeses group (WC) is clearly separated from the rest of the groups because these cheeses have higher values of ethanol, ethyl acetate, acetaldehyde and 2-butanol, together with lower values of 2-heptanone, 2-pentanone, isopropanol, 2-pentanol, acetone and 2-heptanol. There is a clear difference between the WC and WG winter cheeses and the rest of the cheeses made in summer but this difference is hardly noticeable in the sheep cheeses. The variables propanal together with 2-pentanol, acetone, 2-propanol and isopropanol, although to a lesser extent, clearly separate winter and summer cheeses owing to their lower mean values in winter. Goat's and sheep's milk cheeses were separated by 3-methyl-1-butanol and 3-methyl-1-butanal compounds. This last compound together with acetone and 2-heptatone allow for the differentiation 
between winter and summer goat's milk cheeses. All this indicates that the Canonical biplot is a suitable method for explaining this type of population, in which many different factors are involved.

\section{ACKNOWLEDGMENTS}

J.M. Hernández-Hierro thanks Universidad de Sevilla for the extension of Juan de la Cierva postdoctoral contract.

\section{REFERENCES}

Addis M, Fiori M, Riu G, Pes F, Salvatore E, Pirisi A. 2015. Physico-chemical characteristics and acidic profile of PDO Pecorino Romano cheese: Seasonal variation Small Ruminant Research 126, 73-79. http://dx.doi.org/10.1016/j. smallrumres.2015.03.014.

Amaro IR, Vicente-Villardón JL, Galindo-Villardón MP. 2004. Manova-biplot for two way multivariate general linear models. Interciencia, 29, 26-32, 58-59.

Antoniou KD, Petridis D, Raphaelides S, Ben Omar Z, Kesteloot R. 2000. Texture assessment of French cheeses. J. Food Sci. 65, 168-172. http://dx.doi.org/10.1111/j.1365-2621.2000. tb15974.x

Barrón LJR, Redondo Y, Flanagan CE, Pérez-Elortondo FJ, Albisu M, Nájera AI, Renobales M, Fernández-García E. 2005a. Comparison of the volatile composition and sensory characteristics of Spanish PDO cheeses manufactured from ewes'raw milk and animal rennet. Int. Dairy J. 15, 371-382. http://dx.doi.org/10.1016/j.idairyj.2004.08.005.

Barron LJR, Redondo Y, Ortigosa MA, Carbonell MA, Garcia S, Torre P, Renobales M, Fernández-García E. 2005b. Comparison of dynamic headspace methods used for the analysis of the volatile composition of Spanish PDO ewe's raw milk cheeses. Lait, 85, 491-513. http://dx.doi.org/ 10.1051/lait:2005036.

Barron LJR, Fernandez de Labastida E, Perea S, Chavarri F, Vega C, Soledad Vicente M, Isabel Torres M, Najera AI, Virto M, Santisteban A, Pérez-Elortondo FJ, Albisu M, Salmerón J, Mendía C, Torre P, Ibánez FC, Renobales M. 2001. Seasonal changes in the composition of bulk raw ewe's milk used for Idiazabal cheese manufacture. Int. Dairy J. 11, 771-778. http://dx.doi.org/10.1016/S0958-6946(01)00120-0.

Castillo I, Calvo MV, Alonso L, Juarez M, Fontecha J. 2007. Changes in lipolysis and volatile fraction of a goat cheese manufactured employing a hygienized rennet paste and a defined strain starter. Food Chem. 100, 590-598. http:// dx.doi.org/10.1016/j.foodchem.2005.09.081.

Dahl S, Tavaria FKF, Xavier Malcata F. 2000. Relationships between flavour and microbiological profiles in Serra da Estrela cheese throughout ripening. Int. Dairy J. 10, 255-262. http://dx.doi.org/10.1016/S0958-6946(00)00042-X.

Fedele V, Rubino R, Claps S, Sepe L, Morone G. 2005. Seasonal evolution of volatile compounds content and aromatic profile in milk and cheese from grazing goat. Small Ruminant Res. 59, 273-279. http://dx.doi.org/10.1016/j. smallrumres.2005.05.013.

Fernandez-Garcia E, Carbonell M, Gaya P, Nunez M. 2004a. Evolution of the volatile components of ewes raw milk Zamorano cheese. Seasonal variation. Int. Dairy J. 14, 701-711. http://dx.doi.org/10.1016/j.idairyj.2003.12.011

Fernandez-Garcia E, Gaya P, Medina M,Nunez M. 2004b. Evolution of the volatile components of raw ewes' milk Castellano cheese: seasonal variation. Int. Dairy J. 14, 39-46. http://dx.doi.org/10.1016/S0958-6946(03)00148-1.

Fox PF, Wallace JM. 1997. Formation of flavor compounds in cheese, In Anonymous Adv. Appl. Microbiol. 45, 17-85. http://dx.doi.org/10.1016/S0065-2164(08)70261-2.

Gabriel KR. 1971. The biplot graphic display of matrices with application to principal component analysis. Biometrika, 58, 453-467. http://dx.doi.org/10.1093/biomet/58.3.453.
Gabriel KR, Odoroff CL. 1990. Biplots in biomedical research. Statistics in medicine, 9 (5), 469-485. http://dx.doi.org/ 10.1002/sim.4780090502.

Galindo MP. 1985. Contribución a la representación simultánea de datos multidimensionales. Doctoral thesis. Universidad de Salamanca.

Galindo MP. 1986. Una alternativa de representación simultánea: HJ Biplot. Questio, 10 (1), 13-23.

Gomez-Ruiz JA, Ballesteros C, Vinas MAG, Cabezas L, Martinez-Castro I. 2002. Relationships between volatile compounds and odour in Manchego cheese: comparison between artisanal and industrial cheeses at different ripening times. Lait, 82, 613-628. http://dx.doi.org/10.1051/ lait:2002037.

González-Martín MI, Hernández-Hierro JM, Morón-Sancho R, Salvador-Esteban J, Vivar-Quintana AM, Revilla I. 2007. Determination of the percentage of milk (cow's, ewe's and goat's) in cheeses with different ripening times using nirs technology and a remote reflectance fibre-optic probe. Anal. Chim. Acta, 604, 191-196. http://dx.doi.org/10.1016/j.aca. 2007.10.014

González-Martín MI, Hernández-Hierro JM, Salvador-Esteban J, González Pérez C, Revilla I, Vivar-Quintana AM. 2011. Discrimination of seasonality in cheeses by near infrared technology. J. Sci. Food Agric. 91, 1064-1069. http://dx.doi. org/10.1002/jsfa.4283.

González-Martín MI, Hernández-Hierro JM, González Pérez C, Revilla I, Vivar-Quintana AM, Lobos-Ortega I. 2014. Potential of near infrared spectroscopy for the analysis of volatile components in cheeses. LWT - Food Sci. Technol. 55, 666-673. http://dx.doi.org/10.1016/j.lwt.2013.10.008.

Iñigo AC, Vicente-Tavera S, Rives V. 2004. MANOVA-biplot Statistical Analysis of the Effect of Artificial Ageing (Freezing/Thawing) on the Colour of Treated Granite Stones. Color Res. Appl. 29, 115-120. http://dx.doi.org/ $10.1002 / \mathrm{col} .10236$

Iñigo AC, López-Moro FJ, Vicente-Tavera S, Rives V. 2005. Monitoring of origin and evolution of building stones through their major components. J. Mat. Civil Eng. 17, 440-446. http://dx.doi.org/10.1061/(ASCE)0899-1561(2005)17:4(440).

Iñigo AC, García-Talegón J, Vicente-Tavera S, Martín-González, S. Casado-Marín S, Vargas-Muñoz M, Pérez-Rodríguez JL. 2013. Colour and ultrasound propagation speed changes by different ageing of freezing/thawing and cooling/heating in granitic materials. Cold Regions Sci. Technol. 85,71-78. http://dx.doi.org/10.1016/j.coldregions.2012.08.004.

Innocente N, Munari M, Biasutti M. 2013. Characterization by solid-phase microextraction-gas chromatography of the volatile profile of protected designation of origin Montasio cheese during ripening, J Dairy Sci. 96, 26-32. http://dx.doi. org/10.3168/jds.2012-5689.

Izco JM, Torre P. 2000. Characterisation of volatile flavour compounds in Roncal cheese extracted by the 'purge and trap' method and analysed by GC-MS. Food Chem. 70, 409-417. http://dx.doi.org/10.1016/S0308-8146(00)00100-X.

Johansen AG, Vegarud GE, Skeie S. 2002. Seasonal and regional variation in the composition of whey from Norwegian Cheddar-type and Dutch-type cheeses. Int. Dairy J. 12, 621-629. http://dx.doi.org/10.1016/S0958-6946(02)00054-7.

King ES, Hopfer H, Haug MT, Orsi JD, Heymann H, Crisosto GM, Crisosto CH. 2012. Describing the Appearance and Flavor Profiles of Fresh Fig (Ficuscarica L.) Cultivars. $J$. Food Sci. 77, S419-S429. http://dx.doi.org/10.1111/j.17503841.2012.02994.x

Lobato-Calleros C, Vernon-Carter E, Guerrero-Legarreta I, Soriano-Santos JH. Escalona-Beundia H. 1997. Use of fat blends in cheese analogs: Influence on sensory and instrumental textural characteristics. J. Texture Studies, 28, 619-632. http://dx.doi.org/10.1111/j.1745-4603.1997.tb00142.x.

Molina E, Ramos M, Alonso L, Lopez-Fandino R. 1999. Contribution of low molecular weight water soluble compounds to the taste of cheeses made of cows', ewes' and goats' milk. Int. Dairy J. 9, 613-621. http://dx.doi.org/10.1016/ S0958-6946(99)00131-4.

Nudda A, McGuire MA, Battacone G, Pulina G. 2005. Seasonal variation in conjugated linoleic acid and vaccenic acid in 
milk fat of sheep and its transfer to cheese and ricotta. $J$. Dairy Sci. 88, 1311-1319. http://dx.doi.org/10.3168/jds. S0022-0302(05)72797-1.

Pillonel L, Ampuero S, Tabacchi R, Bosset JO. 2003. Analytical methods for the determination of the geographic origin of Emmental cheese: volatile compounds by $\mathrm{GC} /$ MS-FID and electronic nose. Eur. Food Res. Technol. 21, 179-183.

García-Talegón J, Iñigo AC, Vicente-Tavera S. 2013.“Canonical biplot as tool to detect microclimates in the inner and outer parts of Salamanca Cathedrals". In: Rogerio-Candelera M.A., Lazzari M., Cano E. (Eds.). Science and Technology for the Conservation of Cultural Heritage, Taylor \& Francis Group, London, 59-62.

Rui Alves M, Beatriz Oliveira M. 2003. Interpolative biplots applied to principal component analysis and canonical correlation analysis. J. Chemometrics 17, 594-602. http:// dx.doi.org/10.1002/cem.827.

Sitzia M, Bonanno A, Todaro M, Cannas A, Atzori AS, Francesconi AHD, Trabalza-Marinucci M. 2015. Feeding and management techniques to favour summer sheep milk and cheese production in the Mediterranean environment
Small Ruminant Res. 126, 43-58. http://dx.doi.org/10.1016/j. smallrumres.2015.01.021

Tavaria FK, Silva Ferreira AC, Xavier Malcata F. 2004. Volatile free fatty acids as ripening indicators for Serra da Estrela cheese. J. Dairy Sci. 87, 4064 4072. http://dx.doi.org/10.3168/ jds.S0022-0302(04)73548-1.

Tavaria FK, Tavares TG, Silva-Ferreira AC, Malcata FX. 2006. Contribution of coagulant and native microflora to the volatile-free fatty acid profile of an artisanal cheese. Int. Dairy J. 16, 886-894. http://dx.doi.org/10.1016/j.idairyj. 2005.08.004.

Varas MJ, Vicente-Tavera S, Molina E, Vicente-Villardón JL. 2005. Role of canonical biplot method in the study of building stones: An example from Spanish monumental heritage. Environmetrics 16, 405-419. http://dx.doi.org/ 10.1002/env.722.

Vicente-Villardón JL.1992. Una alternativa a los métodos factoriales clásicos basada en una generalización de los métodos biplot. M.S. Thesis. Universidad de Salamanca. Spain.

Vicente-Villardón JL. 2013. MULTIBIPLOT: Multivariate Analysis using biplots. Departamento de Estadística. Universidad de Salamanca. 